\title{
Heavy Metals Content in Cloves Spices (Syzygium aromaticum) Cultivated in Zanzibar
}

\author{
Fatma Omar Khamis ${ }^{*}$, Suleiman Ameir Suleiman1, Mohmmed Sheikh², Ahmada Omar Ali \\ ${ }^{1}$ Tanzania Atomic Energy Commission, Dar es Salaam, Tanzania \\ ${ }^{2}$ The State University of Zanzibar, Zanzibar, Tanzania \\ ${ }^{3}$ Ardhi University, Dar es salaam, Tanzania \\ Email: ${ }^{\star}$ fatmaomarkhamis@gmail.com
}

How to cite this paper: Khamis, F.O., Suleiman, S.A., Sheikh, M. and Ali, A.O. (2021) Heavy Metals Content in Cloves Spices (Syzygium aromaticum) Cultivated in Zanzibar. Open Access Library Journal, 8: e7502.

https://doi.org/10.4236/oalib.1107502

Received: May 7, 2021

Accepted: June 6, 2021

Published: June 9, 2021

Copyright $\odot 2021$ by author(s) and Open Access Library Inc.

This work is licensed under the Creative Commons Attribution International License (CC BY 4.0).

http://creativecommons.org/licenses/by/4.0/

\begin{abstract}
The concentration of selected heavy metals (Chromium-Cr, Cadmium-Cd and Lead-Pb) collected from different sites of Unguja and Pemba were determined using Energy Dispersive X-Ray Fluorescence (EDXRF). The findings showed that $\mathrm{Cr}$ ranged from 10.3 to $16.25 \mathrm{ppm}$, Cd from 3.39 to 8.00 $\mathrm{ppm}$ and $\mathrm{Pb}$ from 0.35 to1.18 ppm for Pemba Island. For Unguja Island $\mathrm{Cr}$ ranged from (6.65 to $12.3 \mathrm{ppm}$, Cd ranged from (2.61 to 6.00) $\mathrm{ppm}$ and $\mathrm{Pb}$ ranged from ( 0.52 to $0.80 \mathrm{ppm})$. Significant elemental correlation $(p \geq 0.05)$ for all three metals detected from Unguja sites. The metal levels found from both sides of Islands were above standard limits set by FAO and WHO. The results of this study suggest that the levels of toxic metals detected from Zanzibar spices have potential risk to public health.
\end{abstract}

\section{Subject Areas}

Applied Physics

\section{Keywords}

Heavy Metals, Zanzibar, Clove, Spice,

Energy Dispersive X-Ray Fluorescence Spectrometer

\section{Introduction}

Clove is among the most popular spice plant grown in some parts of east Africa, Asia and South America. In Tanzania, cloves syzygium aromaticum are primarily produced in Zanzibar. Clove and its byproduct clove oil have been widely used in a variety of health therapies such as parasitic infections, cosmetics toothaches etc. More commonly, cloves are used as food spices, aroma or flavor and 
cosmetics. Inspite of importance of cloves there is increasing concern over the safety and toxicity due to contamination of various hazardous substances including heavy metals ([1] [2]).

In recent years, there is an increasing involvement in observance heavy metals contamination in various spices which are commonly consumed by people including cloves. These toxic levels on human wellness and the environment have attracted considerable attention in recent years [3]. The toxic metals concentration level is due to their long persistence and accumulation behavior in the environment and ecosystem [4]. Heavy metals contaminate clove trees through soils and atmospheric deposition.

Existence of heavy metals concentration in spices including cloves and their toxicity has been widely reported ([1] [2] [5] [6] [7]). However, there is no published data on heavy metals in clove in Zanzibar. The aim of this study therefore was to determine levels of heavy metal in clove collected from Zanzibar. The analyzed heavy metals were (Lead $(\mathrm{Pb})$, Cadmium $(\mathrm{Cd})$, and Chromium (Cr).

\section{Materials and Methods}

\section{Materials}

A bench top energy dispersive X-ray spectrometer of TAEC in Arusha is the machine used to conduct elemental analyses of samples. The machine is operated by automatic turbo-quant X-lab ProTM software at a rate of $50 \mathrm{~W}$ power and $50 \mathrm{kV}$ voltage. The florescent $\mathrm{X}$-rays were collected by a $\mathrm{Si}(\mathrm{Li})$ detector having a resolution (FWHM) at MnKa $\leq 160 \mathrm{eV}$. A good immovability information and resolution of the peaks obtained by a spectrum which is runs for 15 minutes. The concentration of each elements were determined by using basic parameter method intrinsic in X-lab Pro computer software in which matrix effects was reckoning for.

Quality control was carried out using IAEA reference material Trace and Minor Elements in Cabbage (IAEA 359) analyzed with the samples and another reference standard from TAEC results expressed in ppm of dry weight and evaluated by comparing with MPL of the basis of FAO/WHO.

\section{Methods}

Samples of cloves buds were collected from two regions, North Unguja (Chaani and Mahonda) and South Pemba (Chokocho, Kinyasini, and Ziwani). The sites labelled by letter A, B, C, D and E as representative for Kinyasini, Ziwani, Chokochoko, Chaani and Mahonda respectively. The samples were purchased from sites which are among high clove yield areas in Unguja and Pemba. (15 samples of cloves, purchased from farmers, chopped, separated from bud, stem and leaves, to facilitate drying) the clove were taken from five area in same sites and processed separately. The results were then taken by averaged them to have one result for statistical analysis. 
The samples then sun and oven dried at $80^{\circ} \mathrm{C}$ for $6 \mathrm{~h}$. The dried samples were then ground in a motor with pestle till a fine powder was obtained. The powder then sieved to obtain a less than $0.07 \mathrm{~mm}$ size before put in to clean polyethylene bags and send to (TAEC) laboratory for analysis by using (EDXRF) equipment. A sample of $5 \mathrm{~g}$ of mixed sieved powder mixed carefully, uniformity and be compressed into pellets of diameter of $32 \mathrm{~mm}$ to give reproducible irradiation and counting geometry.

\section{Statistical Analysis of Data}

The accuracy and precision of the EDXRF method was assured by simultaneous analysis of the reference material (Spinach vegetable sample) provided by the IAEA. The results were expressed in ppm of dry weight. The evaluation is done by comparison with the maximum allowable Limits (mPL) on the ground of FAO/WHO. Descriptive statistical parameters (Mean, Range and Standards deviation) calculated using the statistical Package for ANOVA and Sigma Plot of version-12. F-and Tukey HSD testing of ANOVA was employed to detect significant differences among means. Data are presented as Mean \pm standard deviation where a statistically significant level was considered, using probability coefficient correlation $\mathrm{p}<0.05$. A probability level of $\mathrm{p}<0.05$ was considered statistically significant, reported values obtained through calculation. As Table 1 shown, the experimental values were all in good accord with the recommended values within $13 \%$ accuracy.

\section{Results}

The level of $\mathrm{Cr}, \mathrm{Cd}$ and $\mathrm{Pb}$ in clove buds and their descriptive parameters in statistics are shown in Table 2. For all sites in Unguja and Pemba while, Table 3 and Table 4 for Pemba and Unguja pooled values.

Table 1. Maximum allowable limits of heavy metals $(\mathrm{Cr}, \mathrm{Cd}$ and $\mathrm{Pb})$ in plants set by FAO/WHO.

\begin{tabular}{ccc}
\hline Elements & Symbol & Maximum permissible limit (MPL) \\
\hline Chromium & $\mathrm{Cr}$ & $2.00 \mathrm{mg} / \mathrm{kg}$ \\
Cadmium & $\mathrm{Cd}$ & $3 \mathrm{ppm}$ \\
Lead & $\mathrm{Pb}$ & $1 \mathrm{ppm}$ \\
\hline
\end{tabular}

Table 2. Shows the representative control measured values for accuracy of sample.

\begin{tabular}{cccc}
\hline Name of elements & $\begin{array}{c}\text { Measured value } \\
(\mathrm{ppm})\end{array}$ & $\begin{array}{c}\text { Standard dev. } \\
(\mathrm{ppm})\end{array}$ & $\begin{array}{c}\text { Actual value } \\
(\mathrm{ppm})\end{array}$ \\
\hline Chromium & 18.25 & 18.25 & 0.5 \\
Cadmium Cd & 4.5 & 0.9 & 3.98 \\
Lead $\mathrm{Pb}$ & 0.7 & 0.1 & 0.9 \\
\hline
\end{tabular}


Table 3. Average concentration of $\mathrm{Cr}, \mathrm{Cd}$ and $\mathrm{Pb}$ for clove buds cultivated in Zanzibar from each site with its standard deviation and ranges.

\begin{tabular}{cccc}
\hline Elements & $\mathrm{Cr} \pm \mathrm{SD}(\mathrm{ppm})$ & $\mathrm{Cd} \pm \mathrm{SD}(\mathrm{ppm})$ & $\mathrm{Pb} \pm \mathrm{SD}(\mathrm{ppm})$ \\
\hline Sites & & & \\
\hline \multirow{2}{*}{$\mathrm{A}$} & $12.26 \pm 0.52$ range & $6.17 \pm 1.0$ range & $0.74 \pm 0.08$ range \\
& $(10.35-13.35)$ & $(3.48-8.00)$ & $(0.59-1.18)$ \\
& $18.62 \pm 0.9$ range & $4.28 \pm 0.71$ range & $0.4 \pm 0.06$ range \\
$\mathrm{B}$ & $(15.8-21.3)$ & $(3.39-5.3)$ & $(0.35-0.47)$ \\
& $6.13 \pm 0.6$ range & $5.45 \pm 0.6$ range & $0.36 \pm 0.08$ range \\
$\mathrm{C}$ & $(5.2-7.45)$ & $(3.39-7.13)$ & $(0.29-0.41)$ \\
& $7.27 \pm 0.9$ range & $4.49 \pm 0.48$ range & $0.84 \pm 0.08$ range \\
& $(5.85-9.3)$ & $(2.6-6.00)$ & $(0.65-0.89)$ \\
$\mathrm{D}$ & $10.5 \pm 0.8$ range & $5.03 \pm 0.38$ range & $0.52 \pm 0.08$ range \\
& $(9.3-11.65)$ & $(2.78-6.9)$ & $(0.47-0.59)$ \\
\hline
\end{tabular}

Table 4. Average concentration of metals from Unguja and Pemba sites only with their descriptive statistics (mean, SD and Range).

\begin{tabular}{cccc}
\hline Region & Chromium & Cadmium & Lead \\
\hline \multirow{2}{*}{ Pemba } & $13.52 \pm 0.4$ & $4.84 \pm 0.3$ & $0.7 \pm 0.6$ \\
& $(10.3-16.25)$ & $(3.9-8.00)$ & $(0.35-1.18)$ \\
Unguja & $10.43 \pm 0.5$ & $4.76 \pm 0.4$ & $0.68 \pm 0.2$ \\
& $(6.65-12.3)$ & $(2.61-6.00)$ & $(0.4-0.97)$ \\
\hline
\end{tabular}

Average concentration of metals from Unguja and Pemba sites only with their descriptive statistics (mean, Standard deviation and Range).

The pooled content of $\mathrm{Cr}, \mathrm{Cd}$ and $\mathrm{Pb}$ Table 4, in clove buds from Unguja and Pemba were measured, compared with maximum permissible limit of FAO/WHO in Table 2 \& Table 3 above, the level of content also compared with other studies value as determined by other suitable standards applied to other spices and condiments from various places.

The results revealed the concentration of metals from Pemba varies from (10.3 16.25) ppm, (3.39 - 8.00) ppm and (0.35 - 1.18) ppm for $\mathrm{Cr}$, $\mathrm{Cd}$ and $\mathrm{Pb}$ respectively, while chromium $\mathrm{Cr}$, Cadmium $(\mathrm{Cd})$ and $\mathrm{Pb}$ ranged (6.65 - 15.5) ppm, $2.61-6.96$ and (0.47 - 0.97) in Unguja sites which are higher than the maximum permissible limit in all sites from unguja and Pemba.

The average concentration variation of metal in Figure 1, show that as all elements increases at site number five to other sites.

\subsection{Chromium Cr}

Food is a major source of exposure of chromium to human [8], but excessive intake particularly of more oxidizing $\mathrm{Cr}(\mathrm{VI})$ can harm biological system [9]. The knowledge of $\mathrm{Cr}$ has recently received much attention to its importance as an essential element in human body metabolic process and improvement of glucose tolerance special $\mathrm{Cr}(\mathrm{III}),[10]$ and its carcinogenic effects in case of excessive 
Graph shows variation of $\mathrm{Cr}, \mathrm{Cd}$ and $\mathrm{Pb}$ in clove buds of Zanzibar.

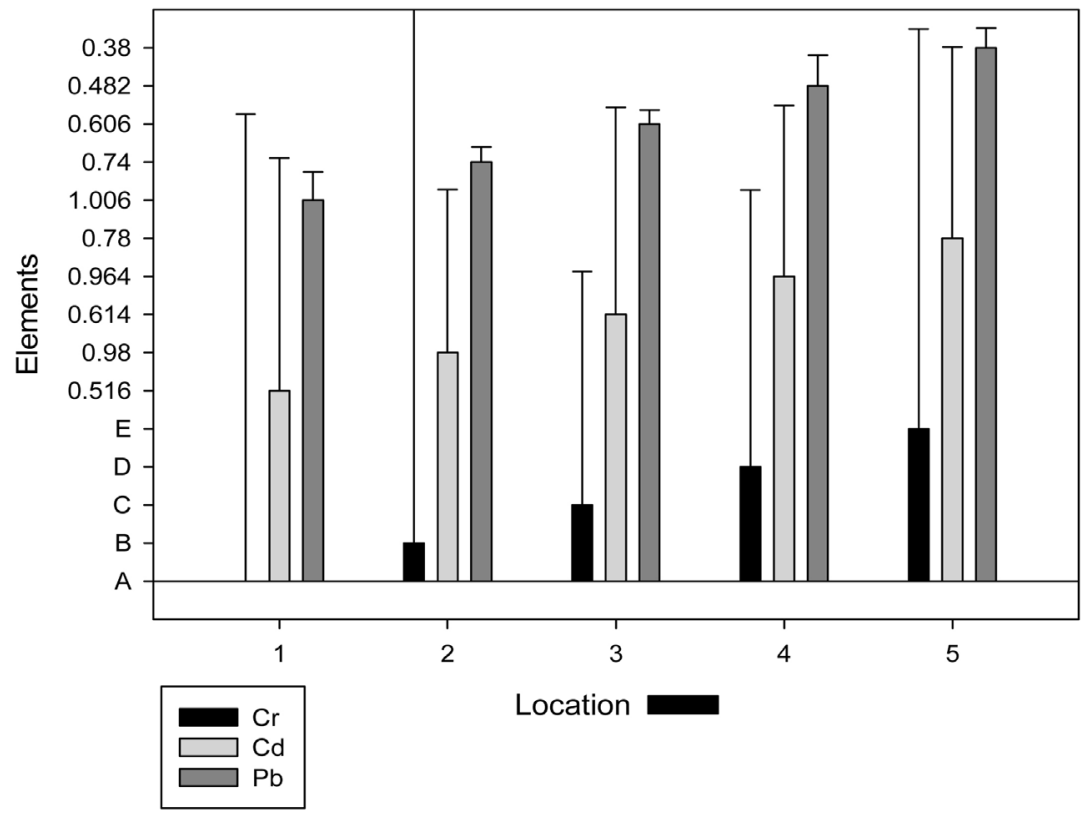

Figure 1. Variation of $\mathrm{Cr}, \mathrm{Cd}$ and $\mathrm{Pb}$ in clove.

uptake, particularly $\mathrm{Cr}(\mathrm{VI})$. Maximum concentration of $\mathrm{Cr}$ was found to be higher in all five sites from Unguja and Pemba. The result show that, the accumulation of $\mathrm{Cr}$ from all locations was well above permissible limits recommended by $\mathrm{FAO} / \mathrm{WHO}$. The average concentration of Chromium $\mathrm{Cr}$ in clove buds from Pemba ranged from $(5.2 \pm 0.6 \mathrm{ppm}$ site $\mathrm{C}$ to $21.3 \pm 0.9 \mathrm{ppm}$ site $\mathrm{B}$, even the lower limit of range is above the value set by spice regulatory bodies such as FAO/WHO, a maximum permissible limit of $2.00 \mathrm{~mm} / \mathrm{kg}$ for spice, while at Unguja sites ranged from $585 \pm 0.9 \mathrm{pmm}$ site $\mathrm{D}$ to $11.65 \pm 0.8 \mathrm{ppm}$ site $\mathrm{E}$ the results shows that evidently all $\mathrm{Cr}$ value were above $\mathrm{FAO} / \mathrm{WHO}$ limits. Maximum concentration of chromium was found at site B $18.62 \pm 0.9 \mathrm{ppm}$ where minimum concentration of $\mathrm{Cr}$ was observed $6.13 \pm 0.6 \mathrm{ppm}$ at site $\mathrm{C}$. The level recorded in this study is generally higher than the level recorded in the literatures. The study by [11] shows value of chromium in spices as 115 to 368 $\mathrm{mg} / \mathrm{kg}$ which is above permissible level of WHO of $100 \mathrm{mg} / \mathrm{kg}$ of spices.

\subsection{Lead Pb}

As revealed by data concentration of $\mathrm{Pb}$ varied from 0.35 - $1.18 \mathrm{ppm}$ from Pemba Island and $0.4-0.97 \mathrm{ppm}$ Unguja Island. Maximum value of $\mathrm{Pb}$ found at site $\mathrm{D}$ which varied $0.65-1.18$ with average concentration of $0.84 \pm 0.08 \mathrm{ppm}$ while the lowest concentration detected from site $\mathrm{C}$ as 0.29 - 0.41 with average concentration of $0.36 \pm 0.08 \mathrm{ppm}$. All the samples from five locations recorded less than half of $1 \mathrm{mg} / \mathrm{kg}$ the WHO standard limit for $\mathrm{Pb}$ in the clove spice. Hence the $\mathrm{Pb}$ levels of the clove bud samples are relatively very tolerable that consumer are safe from exposure resulted from consuming such spices. The study of [12] reported a concentration of $5.1 \mathrm{ppm}$ of $(\mathrm{Pb})$ which is much higher than allowed 
limits in spices amount to $1 \mathrm{ppm}$ according to the World Health Organization (WHO) [13]. Accumulative impacts of $(\mathrm{Pb})$ can cause kidney damage, reduce fertility, and increase the chance of occurrence of the failure of the pregnancy or the occurrence of congenital malformations, anemia, colic, headache, brain damage and central nervous system disorder [14], In addition, $\mathrm{Pb}$ can affect human body and can cause nausea anemia, abdominal pain, vomiting and paralysis in the joints. High-level exposure in men can damage the organs responsible for sperm production [15].

\subsection{Cadmium Cd}

Cadmium is well thought out as one of the most toxic metal that exhibit highly adverse effect on human health. The main toxicity of Cadmium mostly effect kidney, it also connected with lung damage and bony changes in people worked in affected areas. In safe soil Cd is governed by soil texture $0.2-0.8$ loamy soil and $0.02-0.3$ sandy soil. Since cadmium get into plant from air or soil source, its availability to plant depend on the polluted site. In this study $\mathrm{Cd}$ ranged from 3.9 $8.00 \mathrm{ppm}$ for Pemba Island with average concentration $4.84 \pm 0.3 \mathrm{ppm}$ and 2.61 $6.00 \mathrm{ppm}$ from Unguja Island. The highest was $8.00 \mathrm{ppm}$ at Site A Pemba and the lowest 2.9 at site D Unguja Island. Compare to other studies on heavy metals in spices, Cd in this study was higher than the range $0.011-1.389 \mathrm{mmg} / \mathrm{kg}$ by [16] in spices at Iraq. Study by [1] reported a range of $0.04 \mathrm{ppm}-0.4 \mathrm{ppm}$ amount for Cd level in spices while [17], recorded value of Cd ranged $0.03-0.31$ ppm, [12] report $\mathrm{Cd}$ in spices varied from $(0.71-1.89) \mathrm{ppm}$ which are within permissible limits, of $3 \mathrm{ppm}$, according the [13].

\section{Conclusion}

This study presents the toxic metal level in spices collected from Zanzibar. Most of the levels have exceeded the permissible level of international standards i.e. FAO/WHO. The study suggests that there is a necessity of monitoring the levels of heavy metals in spices commodities for the purpose of safeguarding both environmental and public health.

\section{Acknowledgements}

We are thankful to Tanzania Atomic Energy commission for all instruments to free used and allowing us to undertake the laboratory activities and funding the study as well.

\section{Conflicts of Interest}

The authors declare no conflicts of interest regarding the publication of this paper.

\section{Disclosure Statement}

The Authors declare that there are no conflicts of interest regarding the paper, it 
has not been presented anywhere.

\section{References}

[1] Inam, F., Deo, S. and Narkhed, N. (2013) Analysis of Minerals and Heavy Metals in Some Spices Collected from Local Market. IOSR Journal of Pharmacy and Biological Sciences, 8, 40-43. https://doi.org/10.9790/3008-0824043

[2] Gaya, U.I. and Ikechukwu, S. (2016) Heavy Metals Contamination of Selected Spices Obtained from Nigeria. Journal of Applied Sciences and Environmental Management, 20, 681-688. https://doi.org/10.4314/jasem.v20i3.23

[3] Huang, L.L., Rad, S., Xu, L., Gui, L.Y., Song, X.H., Li, Y.H., Wu, Z.Q. and Chen, Z.B. (2020) Heavy Metals Distribution, Sources, and Ecological Risk Assessment in Huixian Wetland, South China.

[4] Ali, H., Khan, E. and Ilahi, I. (2019) Environmental Ecotoxicology Chemistry Hazardous of Heavy Metals: Environmental Persistence, Toxicity and Bioaccumulation. Hindawi Journal of Chemistry, 2019, Article ID: 6730305.

https://doi.org/10.1155/2019/6730305

[5] Krejpcio, Z., Krol, E. and Sionkowski (2006) Evaluation of Heavy Metals Contents in Spices and Herbs Available on the Polish Market. Polish Journal of Environmental Studies, 16, 97-100.

[6] Krejpcio, Z., Krol, E. and Sionkowski, S. (2007) Evaluation of Heavy Metals Contents in Spices and Herbs Available on the Polish Market. Polish Journal of Environmental Studies, 16, 97-100.

[7] Seddigi, Z.S., Kandhro, G.A., Shah, F., Danish, E. and Soylak, M. (2016) Assessment of Metals Contents in Spices and Herbs from Saudi Arabia. Toxicology \& Industrial Health, 32, 260-269. https://doi.org/10.1177/0748233713500822

[8] WHO (2008) Guidelines for Drinking-Water Quality. 3rd Edition, World Health Organization, Geneva.

[9] Michalski, R. (2004) Ion Chromatography Method for the Determination of Trace Levels of Chromium (VI) in Water. Polish Journal of Environmental Studies, 13, 73-77.

[10] Mandiwana, K.L., Panichev, N. and Resane, T. (2006) Electro Thermal Atomic Absorption Determination of Total and Hexavalent Chromium in Atmospheric Aerosols. Journal of Hazardous Materials B, 136, 379-382. https://doi.org/10.1016/j.jhazmat.2005.12.030

[11] Mubeen, H., Naeem, I., Takeen, A. and Saddiqe, Z. (2009) Investigations of Heavy Metals in Commercial Spices Brands. New York Science Journal, 2, 20-26. http://www.sciencepub.net/newyork

[12] Jalut, K.K., Kareem, A.N., Ayyas, M.A., Salman, B.M., Jessim, A.I. and Nawar, M.S. (2014) Detection and Estimation of Metals and Toxic Heavy Metals in Imported Spices. Journal of Genetic and Environmental Resources Conservation, 2, 315-317.

[13] World Health Organization (WHO) (2012) Monographs on Selected Medicinal Plants. Vol. 1. Geneva.

[14] Rehman, A., Ullah, H., Khan, R.U. and Ahmad, I. (2013) Population Based Study of Heavy Metals in Medicinal Plant Capparis deciduas. Internal Journal of Pharmacy and Pharmaceutical Sciences, 5, 108-113.

[15] ATSDR (Agency for Toxic Substances and Disease Registry) (2000) Case Studies in Environmental Medicine: Lead Toxicity. U.S. Department of Health and Human Services, Public Health Service, Atlanta. 
[16] Matloob, M.H. (2016) Using Stripping Voltammetry to Determine Heavy Metals in Cooking Spices Used in Iraq. Polish Journal of Environmental Studies, 25, 2057-2070. https://doi.org/10.15244/pjoes/62401

[17] Shim, J., Cho, T., Leem, D., Cho, Y. and Lee, C. (2019) Heavy Metals in Spices Commonly Consumed in Republic of China. https://pubmed.ncbi.nlm.nih.gov 